\title{
OUTLOOK
}

\section{Conducting the finale of DNA replication}

\author{
David Akopian $^{1,2}$ and Michael Rape ${ }^{1,2}$ \\ ${ }^{1}$ Howard Hughes Medical Institute, University of California at Berkeley, Berkeley, California 94720, USA; ${ }^{2}$ Department \\ of Molecular and Cell Biology, University of California at Berkeley, Berkeley, California 94720, USA
}

\begin{abstract}
Anomalies in dismantling the machinery of DNA replication can compromise genome integrity and contribute to tumorigenesis and aging. In this issue of Genes \& Development, Dewar and colleagues (pp. 275-290) identified an E3 ubiquitin ligase, CUL2 ${ }^{\mathrm{LRR} 2}$, that modifies a subunit of the replicative CMG (Cdc45, minichromosome maintenance [MCM] subunits 2-7, and the GINS complex) helicase and triggers disassembly of the replication machinery. Their study offers critical insight into the mechanism of DNA replication termination while at the same time raising important questions for future research.
\end{abstract}

During cell division, every human cell faces the daunting task of faithfully replicating once, but only once, the $\sim 6 \times$ $10^{9}$ nucleotides of genomic information that are strung into DNA molecules and packaged as chromatin. Mistakes in DNA replication introduce mutagenic DNA lesions or genomic instability, both of which have been linked to the emergence of many diseases, including cancer. To ensure that DNA replication occurs as accurately as possible, this process is broken down into separate steps -licensing, initiation, elongation, and termination-that are carried out at distinct cell cycle stages and depend on a set of tightly regulated factors (Siddiqui et al. 2013). A central player in DNA replication is the CMG helicase, which is composed of Cdc45, minichromosome maintenance (MCM) subunits 2-7, and the GINS complex. Formation of an active CMG helicase occurs at licensed replication origins during early $S$ phase and initiates DNA synthesis by unraveling DNA strands to allow polymerases access to their substrate. The CMG helicase and its main partner in crime, DNA polymerase $\varepsilon$, then travel along the leading strand of the replicating chromosomes until two replication forks converge, the daughter DNA duplexes are ligated and decatenated, and the replication machinery is dismantled.

While the initiation and elongation steps of DNA replication have been understood in detail, less is known about the termination phase of this vital process. In part, this has been due to the property of vertebrates to initiate DNA

[Keywords: DNA replication; replication termination; p97; CMG; ubiquitin]

Corresponding author: mrape@berkeley.edu

Article is online at http://www.genesdev.org/cgi/doi/10.1101/gad.297184. 117. replication on $\sim 50,000$ origins at the same time, which results in many unsynchronized termination events and complicates biochemical analyses. The development of a site-specific and synchronous in vitro termination system recently allowed researchers to address this issue and revealed that converging replication forks pass each other unhindered and dissociate only after the replicated dsDNA was ligated and decatenated (Dewar et al. 2015). These findings indicated that the CMG helicase is unloaded from dsDNA in one of the last events, if not the last event, of replication termination.

Release of the CMG helicase from chromatin depends on ubiquitylation of its MCM7 subunit by a CullinRING E3 ubiquitin ligase (Maric et al. 2014; Moreno et al. 2014). Rather than triggering degradation, the modification of MCM7 recruits the p97/VCP segregase, an AAA-ATPase that dismantles protein complexes in a ubiquitin-dependent manner (Franz et al. 2011; Buchberger et al. 2015). Accordingly, p97/VCP extracts ubiquitylated MCM7 from chromatin and thereby releases the CMG helicase and its travel companions from DNA. Whereas the E3 ligase SCF ${ }^{\mathrm{DIA} 2}$ was held accountable for MCM7 ubiquitylation and CMG unloading in yeast (Maculins et al. 2015), its mammalian counterpart had evaded discovery. Without knowing the identity of this enzyme, it had been difficult to unravel the mechanisms that complete replication termination and protect the integrity of our genomic information.

In this issue of Genes \& Development, Dewar et al. (2017) report the successful identification of a vertebrate E3 ligase that ubiquitylates MCM7 and thereby sets the stage for CMG unloading by $\mathrm{p} 97 / \mathrm{VCP}$. The investigators started by developing a plasmid-based system to study synchronous replication termination in egg extracts of the African clawed frog Xenopus laevis. This experimental approach recapitulated findings with sperm DNA showing that MCM7 ubiquitylation and p97/VCP recruitment to chromatin occur only upon termination of DNA replication (Dewar et al. 2015). In addition, replicating plasmids provided a unique opportunity to isolate proteins that associate with DNA at specific times during

(C) 2017 Akopian and Rape This article is distributed exclusively by Cold Spring Harbor Laboratory Press for the first six months after the full-issue publication date (see http://genesdev.cshlp.org/site/misc/terms.xhtml). After six months, it is available under a Creative Commons License (Attribution-NonCommercial 4.0 International), as described at http:// creativecommons.org/licenses/by-nc/4.0/. 
replication, including factors that become entrapped on chromatin if the ubiquitin-dependent extraction of CMG helicases was inhibited. Quantitative mass spectrometry analysis of such candidate regulators of replication termination revealed an E3 ligase that was composed of a Cullin 2 scaffold, an Elongin B/C adaptor, and the leucine-rich repeat protein LRR1 as substrate receptor (referred to here as CRL2 $2^{\mathrm{LRR} 1}$ ). Depletion of CRL2 ${ }^{\text {LRR1 }}$ from Xenopus extracts prevented MCM7 ubiquitylation and strongly delayed extraction of the CMG helicase from chromatin. The depletion of CRL2 $2^{\text {LRR1 }}$ also stabilized many other factors on chromatin that, together with the CMG helicase, form a stable assembly referred to as the vertebrate replisome progression complex and might be involved in different steps of DNA synthesis, including termination. These results therefore pointed toward CRL2 ${ }^{\mathrm{LRR} 1}$ as the major ubiquitin ligase that conducts the final steps of replication termination.

The activity of CRL2 ${ }^{\text {LRR1 }}$ turned out to be tightly regulated. CRL2 $2^{\text {LRR1 }}$ is loaded onto chromatin only after replicated DNA had become ligated and decatenated, an observation that suggests that this E3 ligase selectively recognizes CMG helicases that encircle dsDNA. Its target, MCM7, is also engaged with dsDNA during early stages of replication, before CMG helicases are assembled and the production of ssDNA templates is initiated. However, CRL2 ${ }^{\text {LRR1 }}$ fails to ubiquitylate such MCM7 molecules on licensed but unreplicated DNA, thus providing a safety mechanism against premature termination of DNA replication. As expected from the experiments leading to its discovery, CRL2 ${ }^{\text {LRR1 }}$ engages its substrate only transiently and is released together with the CMG helicase by the action of $\mathrm{p} 97 / \mathrm{VCP}$. Moreover, the role of CUL2 ${ }^{\text {LRR2 }}$ appears to be conserved: While the current studies were performed in Xenopus extracts, genetic interactions between the LRR1 homolog in Caenorhabditis elegans and components of the replication machinery have been reported recently (Ossareh-Nazari et al. 2016). Studies in worms had also indicated that mutations in LRR1 result in genomic instability (Merlet et al. 2010), pointing to an important role for ubiquitin-dependent replication termination in ensuring the integrity of the genomic material.

The exciting results of Dewar et al. (2017) raise many interesting questions. How does CRL2 ${ }^{\mathrm{LRR} 1}$ ensure that only those MCM7 molecules are ubiquitylated that have completed their task in DNA replication? The CMG helicase might undergo a conformational change when it slides onto replicated dsDNA, as opposed to the ssDNA that it encounters while performing its task in replication, and CRL2 ${ }^{\text {LRR1 }}$ might depend on a particular CMG conformation for substrate recognition. To prevent premature modification of MCM7 on licensed but unreplicated DNA, it is possible that CMG helicase subunits might act as coadaptors to improve substrate affinity or selectivity, as seen with other Cullin-RING E3 ligases (McGourty et al. 2016). Moreover, depletion of CRL2 ${ }^{\text {LRR1 }}$ delayed the re- lease of chromatin-bound CMG helicases, while small molecule-dependent inhibition of all Cullin-RING E3 ligases or $\mathrm{p} 97 / \mathrm{VCP}$ obliterated this process. This observation suggests that additional enzymes might provide backup to ensure that termination of DNA replication can occur even if CRL2 ${ }^{\text {LRR1 }}$ activity is compromised. It will be interesting to identify those substitutes, and E3 ligases present in the current proteomic data set provide an interesting starting point. Finally, understanding the recognition of MCM7 by CRL2 $2^{\text {LRR1 }}$ in more detail could yield important tools, such as MCM7 mutants that resist recognition by CRL $2^{\text {LRR1 }}$ and stall DNA replication specifically at the final stage of termination. Such mutants, mimicking the failure of a conductor to bring the concert to a close, would offer a unique opportunity toward identifying the consequences of impaired termination on maintaining genomic integrity.

\section{References}

Buchberger A, Schindelin H, Hanzelmann P. 2015. Control of p97 function by cofactor binding. FEBS Lett 589: 2578-2589.

Dewar JM, Budzowska M, Walter JC. 2015. The mechanism of DNA replication termination in vertebrates. Nature 525: 345-350.

Dewar JM, Low E, Mann M, Raschle M, Walter JC. 2017. CRL2 ${ }^{\text {Lrr1 }}$ promotes unloading of the vertebrate replisome from chromatin during replication termination. Genes Dev (this issue). doi: 10.1101/gad.291799.116.

Franz A, Orth M, Pirson PA, Sonneville R, Blow JJ, Gartner A, Stemmann O, Hoppe T. 2011. CDC-48/p97 coordinates CDT-1 degradation with GINS chromatin dissociation to ensure faithful DNA replication. Mol Cell 44: 85-96.

Maculins T, Nkosi PJ, Nishikawa H, Labib K. 2015. Tethering of SCF(Dia2) to the replisome promotes efficient ubiquitylation and disassembly of the CMG helicase. Curr Biol 25: 2254-2259.

Maric M, Maculins T, De Piccoli G, Labib K. 2014. Cdc48 and a ubiquitin ligase drive disassembly of the CMG helicase at the end of DNA replication. Science 346: 1253596.

McGourty CA, Akopian D, Walsh C, Gorur A, Werner A, Schekman R, Bautista D, Rape M. 2016. Regulation of the CUL3 ubiquitin ligase by a calcium-dependent co-adaptor. Cell 167: 525-538 e514.

Merlet J, Burger J, Tavernier N, Richaudeau B, Gomes JE, Pintard L. 2010. The CRL2 ${ }^{\text {LRR-1 }}$ ubiquitin ligase regulates cell cycle progression during C. elegans development. Development 137: 3857-3866.

Moreno SP, Bailey R, Campion N, Herron S, Gambus A. 2014. Polyubiquitylation drives replisome disassembly at the termination of DNA replication. Science 346: 477-481.

Ossareh-Nazari B, Katsiarimpa A, Merlet J, Pintard L. 2016. RNAi-based suppressor screens reveal genetic interactions between the CRL2 ${ }^{\text {LRR-1 }}$ E3-ligase and the DNA replication machinery in Caenorhabditis elegans. G3 (Bethesda) 6: 3431-3442.

Siddiqui K, On KF, Diffley JF. 2013. Regulating DNA replication in eukarya. Cold Spring Harb Perspect Biol 5: a012930. 


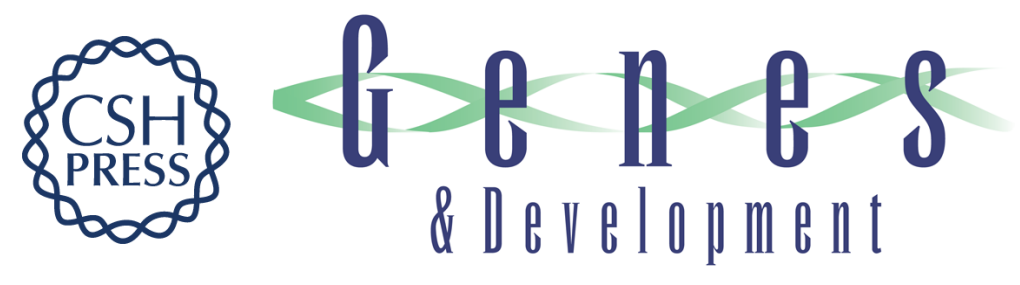

\section{Conducting the finale of DNA replication}

David Akopian and Michael Rape

Genes Dev. 2017, 31:

Access the most recent version at doi:10.1101/gad.297184.117

Related Content CRL2Lrr1 promotes unloading of the vertebrate replisome from chromatin during replication termination

James M. Dewar, Emily Low, Matthias Mann, et al.

Genes Dev. February, 2017 31: 275-290

References This article cites 11 articles, 5 of which can be accessed free at:

http://genesdev.cshlp.org/content/31/3/226.full.html\#ref-list-1

Articles cited in:

http://genesdev.cshlp.org/content/31/3/226.full.html\#related-urls

Creative This article is distributed exclusively by Cold Spring Harbor Laboratory Press for the first Commons License six months after the full-issue publication date (see http://genesdev.cshlp.org/site/misc/terms.xhtml). After six months, it is available under a Creative Commons License (Attribution-NonCommercial 4.0 International), as described at http://creativecommons.org/licenses/by-nc/4.0/.

Email Alerting Receive free email alerts when new articles cite this article - sign up in the box at the top Service right corner of the article or click here.

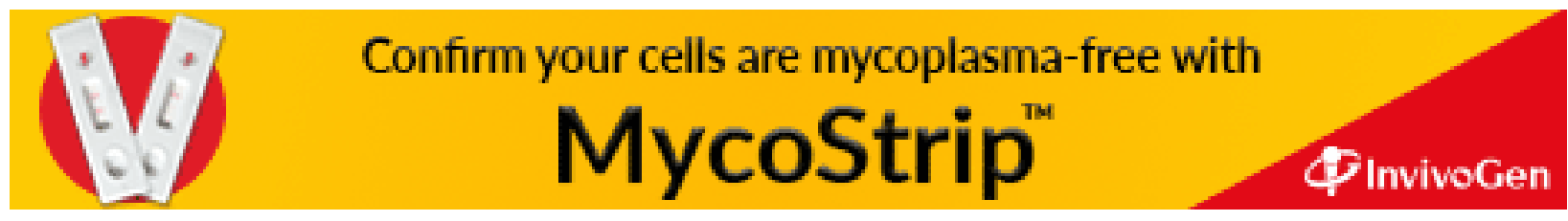

